\title{
Testing road surface treatments to reduce erosion in forest roads in Honduras
}

\author{
Samuel Rivera ${ }^{1}$, Jeffrey L. Kershner ${ }^{2}$, and Gordon R. Keller ${ }^{3}$ \\ ${ }^{1}$ Department of Wildland Resources, Utah State University, Logan, UT 84322-5230. USA. \\ ${ }^{2}$ USGS-BRD-NOROCK PO Box 173492, 211 AJM Johnson Hall Montana State University \\ Bozeman, MT 59717-3492.USA. \\ ${ }^{3}$ US Forest Service Plumas National Forest 59 Lawrence Street \\ Quincy, CA 95971, USA.
}

\begin{abstract}
S. Rivera, J.L. Kershner, and G.R. Keller. 2009. Testing road surface treatments to reduce erosion in forest roads in Honduras. Cien. Inv. Agr. 36(3):425-432. Using forest roads produces more erosion and sedimentation than any other forest or agricultural activity. This study evaluated soil losses from a forest road in central Honduras over two consecutive years. We divided a 400-m segment of road into 8 experimental units, each $50 \mathrm{~m}$ in length. Four units were treated with Best Management Practices (BMPs) and four were left untreated. The BMP treatments included reshaping the road prism, installing culverts and reshaping of road ditches, compacting $20-\mathrm{cm}$ layers of the road tread, crowning the road surface (3\% slope, double drainage), longitudinal sloping (less than $12 \%$ ), and adding a 10-cm layer of gravel (crush size $=0.63 \mathrm{~cm}$ ). Soil movement was measured daily during the rainy seasons. The highest soil loss occurred in the control road, around $500 \mathrm{~m}^{3} \mathrm{~km}^{-1}$ per year, while the road treated with BMP lost approximately $225 \mathrm{~m}^{3} \mathrm{~km}^{-1}$ per year. These results show that road surface erosion can be reduced up to $50 \%$ with the implementation of surface treatments.
\end{abstract}

Key words: Erosion, forest roads, Honduras, road surface, soil, tropical forest.

\section{Introduction}

The majority of sediment production due to forest management practices comes from timber harvests and road construction. The building and maintenance of forest access roads is responsible for more than $90 \%$ of sediment produced during logging operations (Brooks et al., 1991; Megahan, 1980; Sidle, 1980). According to FAO (1989), a road $4 \mathrm{~m}$ wide receiving 390 $\mathrm{cm}$ of rainfall per year with an average slope of $10 \%$ and 6 culverts $\mathrm{km}^{-1}$ could produce as

Received 05 January 2009. Accepted 29 May 2009. Corresponding author: samuel.rivera@aggiemail. usu.edu much as $500 \mathrm{t} \mathrm{km}^{-1}$ sediment per year, depending upon traffic intensity. Coarse and suspended sediment production rates for an unsealed road surface range from 6 to 10 and 14 to $26 \mathrm{t} \mathrm{km}^{-1}$ per year, respectively (Gray and Sotir, 1996). Both coarse and fine particles may settle in adjacent water bodies, resulting in sedimentation of stream channels and reservoirs and deterioration of water quality.

Sediment production by the forest road prism occurs at three critical features: the road surface, cut slopes, and fill slopes. At the road surface, unconsolidated material is susceptible to erosion during precipitation events and may have erosion rates up to 21.5 times higher than that of timber 
harvest areas (Burroughs and King, 1989). Annual sediment production from forest road surfaces is estimated to be 125 to $225 \mathrm{t} \mathrm{km}^{-1}$, two thirds of which is suspended sediment and the rest is coarse material (Gray and Sotir, 1996).

A number of best management practices (BMPs) implemented during forest operations are designed to control pollution-causing activities from forest operations (FAO, 1989). Common road BMPs include impermeable road surface treatments, adequate surface and subsurface drainage structures, and proper location and design of haul roads. Gravel surfacing has proven to be a very effective tool to protect road surfaces. A properly graveled road surface produces less sediment than an unsealed road surface, because an increase in surface roughness reduces raindrop impact and soil particle detachment. Surfacing with durable materials and compaction with blading (grading) are effective techniques to reduce the amount of small soil particles produced on a forest road surface (US Forest Service, 1993). An adequate thickness of surface gravel $(7-10 \mathrm{~cm})$ must be used to ensure durable protection.

The 7,000-km road network in Honduras produces large amounts of sediment. In 2001, only $20.3 \%$ of the roads were paved (World Bank, 2003). The unpaved roads are characterized as low-traffic, constructed in steep mountainous terrain with unconsolidated materials. These roads are used mainly to connect small villages and to provide transportation for products, especially coffee and timber. There are no specific regulations safeguarding water quality during road construction and maintenance. In most cases, water quality protection is ignored by forestry technicians and private companies. There are no regulations for slope protection nor are there standards for the construction and maintenance of road surfaces or drainage. Currently, there is no protection for streamside zones, riparian areas, or municipal watersheds during road construction (Laboranti, 1992).

The objective of this study was to determine and compare soil loss from treated (BMPs implemented) and untreated (traditional road construction practices) sites during and after forest road construction.

\section{Materials and methods}

\section{Study area}

This study was conducted in the pine forests of the National School of Forest Sciences (ESNACIFOR), located $3.5 \mathrm{~km}$ southwest of the town of Siguatepeque, Honduras $\left(13^{\circ}-16^{\circ} \mathrm{N}\right.$, $83^{\circ}-89.5^{\circ} \mathrm{W}$ ) (Figure 1). The school has $42 \mathrm{~km}$ of roads connecting 4,200 ha of forest. This road system is used for all forest management activities, including timber harvesting, reforestation, and fire protection. The forest area is located within the El Cajon watershed, which supplies the nation's largest reservoir and provides $70 \%$ of the country's hydropower (Gollin, 1994). The area is very mountainous, with elevations ranging from 540 to 2,500 $\mathrm{m}$ above sea level. Most of the forest is located on slopes greater than $40 \%$. The soils are well-drained Lithosols of the series Cocona, with a sandy loam texture and a $\mathrm{pH}$ ranging from 5.0 to 6.0 (Laboranti, 1992). Tropical forests are typically associated with coastal mountains receiving high amounts of precipitation, while pine forests containing the headwaters of rivers are found in the mountains of central Honduras.

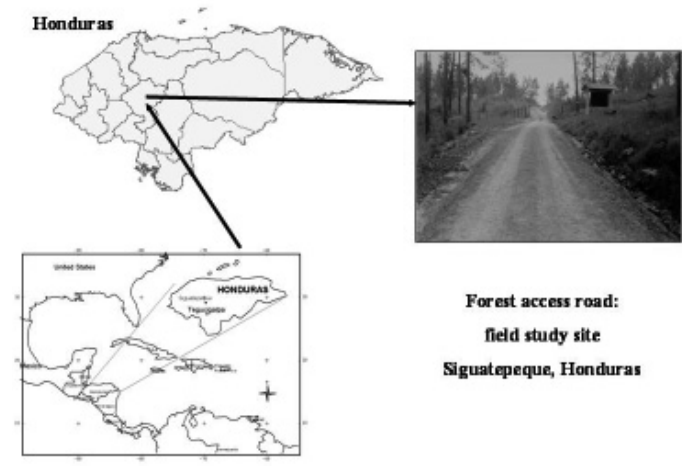

Figure. 1. Location of the study site: Siguatepeque, Honduras.

\section{Methodology}

This study was designed to evaluate the soil loss from road surfaces. In order to test the effectiveness of the road surface treatments, we divided the road into 8 segments, each $50 \mathrm{~m}$ 
long. Four segments were constructed using BMP methods (treated) and the other four were located in a section where traditional road construction methods were used (untreated) (Figure 2).

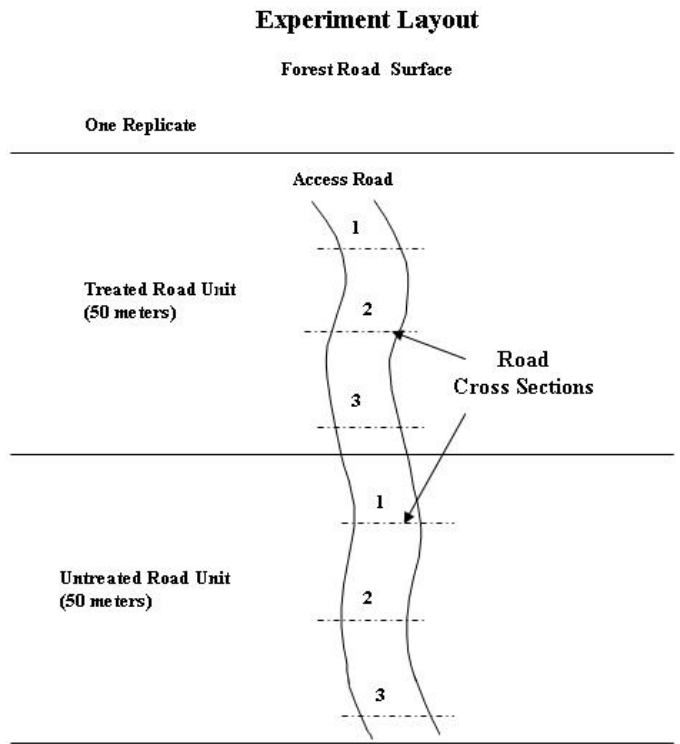

Figure. 2. Layout of the forest road experiment.

The following BMPs were used during the first year of the study: (1) reshaping of the road surface; (2) installation of new and cleaning of existing concrete culverts; (3) compaction of two $20-\mathrm{cm}$ layers of the road tread with selected materials, where the surface was crowned to $3 \%$ slope with double drainage (outslope and inslope surface); (4) improvement and reshaping of road ditches ( $1 \mathrm{~m}$ wide and $0.5 \mathrm{~m}$ deep); and (5) longitudinal slopes less than 12\% (all road segments range between 8 and 12\% slope).

Prior to the first measurement period, all road sections (BMP and traditional) were graded to remove wheel ruts and provide a consistent initial road condition. The control section was located adjacent to the BMP segment in the untreated part of the access road. Both traditional and BMP sections were measured under similar traffic conditions. Traffic was estimated with a traffic counter at a rate of 2,400 vehicle passes per year, including 30\% heavy trucks and $70 \%$ medium and small vehicles. Vehicles speeds rarely exceed $45 \mathrm{~km} \mathrm{~h}^{-1}$. Soil losses were mea- sured using a rill meter, a device designed by the authors to measure the cross section lowering (own design and construction, Siguatepeque, Honduras) (Seyedbagheri, 1996) (Figure 3 ). Each $50-\mathrm{m}$ road segment was divided into three equal sections, and measurements were taken at the end of the first and second third of each segment (Blaney and Warrington, 1983). Thus, 2 measurements (34 readings each) were made in each of the 50-m road segments. Crosssection locations were marked with buried concrete benchmarks. Rills were measured daily during the rainy season. The rill meter not only measures soil losses, but also soil depositions along the road. For the purpose of this study, soil deposition was also considered as a soil loss, because this represents unconsolidated soil particles that will eventually leave the road surface through the road drainage system, producing erosion and sedimentation.

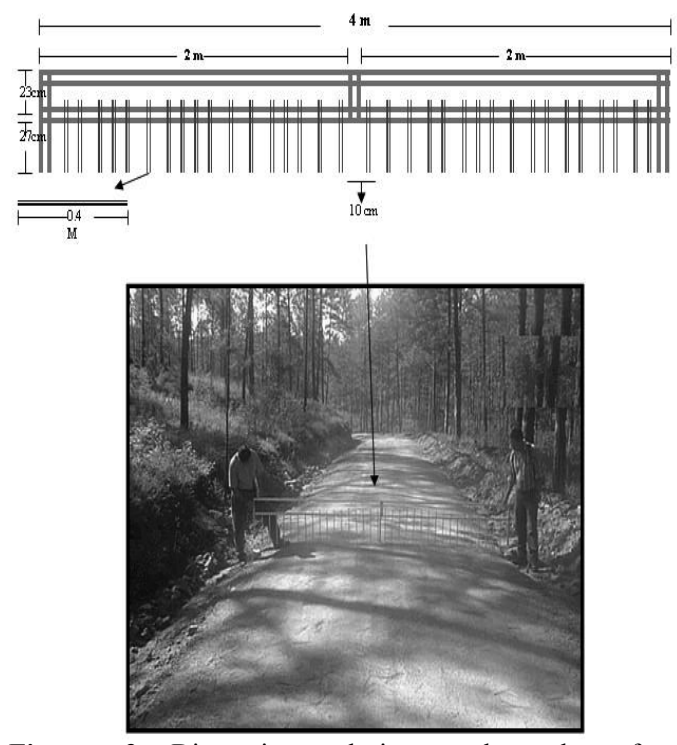

Figure. 3. Dimensions, design, and road surface measurements using the rill meter.

There were no road surface treatments (sealing) in first year. In the second year, a road tread surface treatment was added to the treated road segments. This treatment consisted of a layer of $10 \mathrm{~cm}$ of gravel (washed and crushed at $0.63 \mathrm{~cm}$ $=1 / 4$ inch). Eighty cubic meters of gravel were hauled to the study area and were uniformly distributed along the treated road surface using a grader. 


\section{Design and statistical analysis}

A split plot design was used with time (months) nested within explicit repeated measures to detect differences between treatments throughout the months of the rainy season. Data were first subjected to analysis of variance (ANOVA) (Zar, 1999). The least squares test was used to detect differences among all months. This test provides the best fit between the field-observed values and the values provided by the statistical model (Zar, 1999). Data were log-transformed to meet assumptions of normality. A generalized linear model procedure, Proc GLM (SAS Institute, Inc. Cary, NC, USA) was used to analyze the relationship between erosion and deposition for the BMP-treated segment.

\section{Results}

Soil losses and deposition on the road surface. First year

Unprotected (control) road surfaces produced twice as much as sediment as the BMP-treated road. Due to the large amount of rainfall, some sloughing within the untreated road segment contributed to the much higher soil loss. When the observed soil loss was plotted by month, it became obvious that BMP-treated road segments produced low soil loss during the study period (Figure 4). The highest soil loss occurred in September for both the control road (average $\left.=230 \mathrm{~m}^{3} \mathrm{~km}^{-1} ; \mathrm{SD}=76.7\right)$ and the BMP road (average $\left.=128.5 \mathrm{~m}^{3} \mathrm{~km}^{-1} ; \mathrm{SD}=42.3\right)$ (Figure 4, Table 1). Soil loss was lowest in July (control road average $=41.5 \mathrm{~m}^{3} \mathrm{~km}^{-1}, \mathrm{SD}=23$; BMP road $=10.5 \mathrm{~m}^{3} \mathrm{~km}^{-1}, \mathrm{SD}=11.2$, Table 1). There was a significant difference in sediment production between the treated and untreated road segments (ANOVA; $p=0.019$, Table 1). There was also a significant difference in sediment production during the four months of the rainy season (ANOVA; $p<0.001$, Table 1). Significant dif- ferences occurred between treatments for all months ( $\mathrm{p}<0.001$, Table 1) except August and October $(p=0.2974)$. Sediment yield increased as the rainy season developed, and then decreased toward the end of the rainy season to baseline values (August); however, no significant interactions were found between months and treatments (ANOVA; $p<0.312$, Table 1).

Table 1. Analysis of variance of soil losses and logtransformed soil deposition for the road surface experiments.

\begin{tabular}{llll}
\hline Source & d.f. & F & p \\
\hline
\end{tabular}

\begin{tabular}{|c|c|c|c|}
\hline Treatment & 1 & 10.19 & 0.019 \\
\hline Time & 3 & 17.75 & $<0.0001$ \\
\hline Treatment $\mathrm{x}$ time & 3 & 1.28 & 0.3121 \\
\hline
\end{tabular}

Log-transformed soil deposition for the road surface experiment in year 1

$\begin{array}{llll}\text { Treatment } & 1 & 4.90 & 0.0687 \\ \text { Time } & 3 & 23.06 & <0.0001 \\ \text { Treatment x time } & 3 & 0.64 & 0.5982\end{array}$

Soil losses for the road surface experiment in year 2

$\begin{array}{llll}\text { Treatment } & 1 & 1.02 & 0.3520 \\ \text { Time } & 3 & 3.72 & 0.0554 \\ \text { Treatment x time } & 3 & 1.03 & 0.3861\end{array}$

Log-transformed soil deposition for the road surface experiment in year 2

\begin{tabular}{llll} 
Treatment & 1 & 0.14 & 0.7254 \\
Time & 3 & 6.32 & 0.0134 \\
Treatment x time & 3 & 0.33 & 0.7263 \\
\hline
\end{tabular}

Soil deposition consists of particles eroded from the road surface which are then moved along the road. These soil particles deposit into the road ditches and are finally transported to a given point within the watershed. Soil deposition increased as the rainy season developed and then decreased toward the end of the rainy season to the August values. Soil deposition values for the rainy season of the first year were slightly lower than the values of road surface's soil loss for both the control and the BMP road (Figure 4). 


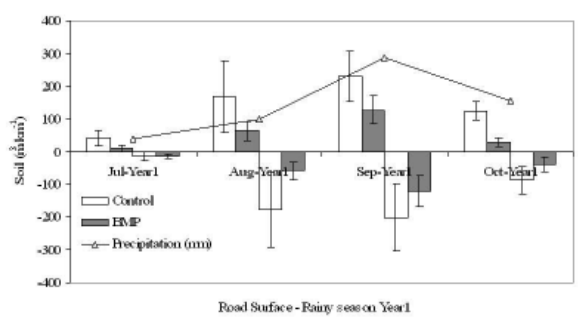

Figure. 4. Soil loss and deposition from the experimental road in year 1. BMP-treated road segments are compared with the untreated (control) road segments. Positive values represent soil loss and negative values indicate soil deposition along the road during the study period. Monthly precipitation values are also shown in the same $\mathrm{Y}$ axis.

The highest soil deposition occurred during September, and the lowest in July. There was no difference between treatments (ANOVA, $\mathrm{p}=$ 0.0687 , Table 1), but there was a highly significant difference in the soil deposition values for the four months of the rainy season (ANOVA, $\mathrm{p}<0.001$, Table 1). There were also significant differences among all months $(\mathrm{p}<0.001)$, except for the individual deposition rates between August and September, and August and October $(\mathrm{p}=0.2974)$. There were no significant interactions between treatments and months (ANOVA, $\mathrm{p}=0.598$, Table 1).

Soil loss and deposition on the road surface. Second year

In year 2, a single BMP (10 cm of gravel) was applied to the treated road while the control road remained untreated. No significant differences were found between treatments for soil loss or for soil deposition (ANOVA, $\mathrm{p}=0.352$ ). The highest soil loss at the control road occurred in September (average $=158 \mathrm{~m}^{3} \mathrm{~km}^{-1} ; \mathrm{SD}=82.9$ ), while the BMP road produced an average of 116 $\mathrm{m}^{3} \mathrm{~km}^{-1}(\mathrm{SD}=55.4)$ (Figure 5, Table 1). The lowest amount of soil loss occurred in August (control road average $73.5 \mathrm{~m}^{3} \mathrm{~km}^{-1}, \mathrm{SD}=46.7$; BMP road average $95 \mathrm{~m}^{3} \mathrm{~km}^{-1}, \mathrm{SD}=62.3$, Table 1 .
There was a significant difference in the amount of soil loss during the three months of the rainy season (ANOVA, $p=0.013$ ), but there was no significant interaction between treatments and months (ANOVA, $p=0.386$, Table 1), indicating that the gravel treatment did not have an effect in those months. In addition, there was no significant difference between August and October $(\mathrm{p}=0.513)$ but there was a significant difference between September and October $(p=0.022)$.

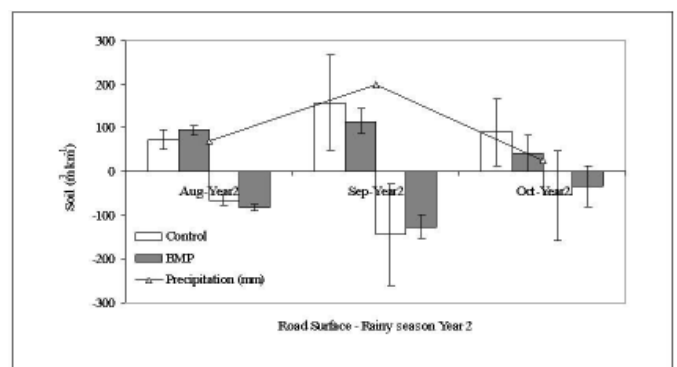

Figure 5. Soil loss and deposition from the experimental road in year 2. BMP-treated road segments are compared with the untreated (control) road segments. Positive values represent soil loss and negative values indicate soil deposition along the road during the study period. Monthly precipitation values are also shown in the same $\mathrm{Y}$ axis.

Soil deposition was slightly lower than soil loss for both the control and the BMP road in the second year (Figure 5). The highest rate of soil deposition occurred in the month with the highest precipitation (September) and the lowest occurred in the month with the lowest precipitation (October). There was no difference between treatments (ANOVA, $\mathrm{p}=0.725$, Table 1), but there was a significant difference between the values of soil deposition during the three months of the rainy season (ANOVA, $\mathrm{p}=0.013$, Table 1). There was no significant interaction between treatments and months (ANOVA, $\mathrm{p}=$ 0.726 , Table 1).

\section{Discussion}

Based on the results obtained, road surface erosion can be reduced up to $50 \%$ with the imple- 
mentation of a combined set of BMPs that increase road base compaction and improve water movement over the road surface. Gravel surfacing has proven to be a very effective tool to protect road surfaces (US Forest Service, 1993). Its high cost aside, this treatment was not very effective in reducing erosion on this type of road (low volume and low traffic forest roads). This might be attributed to the short study period and the fact that the road surface (at the control segments) was already compacted such that little soil particle movement occurred. In addition, measuring the road surface with the rill meter may be inappropriate after applying a $10-\mathrm{cm}$ layer of gravel because the rill meter's pins may go into the interstitial spaces of loose gravel and the measurements may not be accurate. Runoff plots might be a better method of measuring road surface treated with gravel. In general, we believe that the BMPs tested during the first year of experiments should be enough to protect the road surface, so long as they are properly implemented.

Interpreting the results of soil deposition on forest roads may be confusing. Soil loss is often referred to as erosion and the gain or deposition is also referred to as sedimentation. Erosion is the soil movement produced by raindrops or overland flow (in the case of water erosion), and sedimentation refers to the past deposition of soil particles at a given drainage reference point (Megahan, 1980). In the present work, a relationship between soil erosion and deposition was observed throughout the two years of the study. There was a good linear relationship between erosion and deposition for the BMP-treated segments $\left(\mathrm{r}^{2}=0.84\right.$, Standard Error $[\mathrm{SE}]=$ $34 \%$ ) and a less robust relationship for the control road segments $\left(r^{2}=0.69, \mathrm{SE}=50 \%\right)$. When the control and BMP segments were combined, a relationship between erosion and deposition $\left(\mathrm{r}^{2}\right.$ $=0.70, \mathrm{SE}=48 \%$ ) was also observed. Most soil erosion from the road surface occurred when there was increased rainfall. In fact, a strong relationship $\left(r^{2}=0.91, \mathrm{SE}=61 \%\right)$ between rainfall and erosion has been observed in previous studies (Rivera et al., 2008). This may be attributed to the fact that soil erosion occurs immediately after the rainfall event while deposition occurs afterwards, when soil particles settle along the road profile.

The highest soil erosion occurred in September, the month with the highest recorded precipitation, while October was the highest month for deposition. By October, soil has detached from the road surface and was found down the slope and deposited along the road. Because soil loss was slightly higher than soil deposition, it is assumed that the difference left the road surface through ditches. For both soil deposition and soil erosion, the observed variations were not a result of the treatments, and were probably due to differences in seasonal precipitation.

In general, the testing of the above-mentioned BMPs indicated that compaction of the road surface and the road drainage system were the most important practices to reduce soil erosion. Compaction and shaping (crowned surface) of the road prevents water from penetrating the road surface, which reduces pooling and allows for the dispersal of surface water. This drainage protects the road configuration by dispersing the concentrated flows that are associated with high water erosion and transport. Road drainage may be critical in controlling surface flows during high-intensity rain events in the tropics. The combined effect of the above mentioned BMPs reduced erosion at our study site by almost half.

Long-term studies should explore how far down the slopes soil particles are moving. The sediment delivery ratio (SDR) is the ratio of sediment or soil delivered at a given point in the watershed coming from all upland sources above that point (Lal, 1975). At the watershed scale, sediments from recently constructed roads are increased by a factor of five, while at the construction site, they are increased by a factor of 
about 500 (Seyedbagheri, 1996). This indicates that there is slope storage of sediments along the hillslope profile and the road. We assumed that the percent of sediments reaching stream channels might be very low with the implementation of the tested road BMPs (reducing half of the produced erosion). The SDR may provide the exact amount of sediment that reaches the down slope water resources.

\section{Acknowledgments}

We would like to thank to the sponsor of this research project: the U.S. Department of Agriculture through the Foreign Agricultural Service and the International Cooperation Scientific Exchange Program. The USFS- Fish and Ecology Unit at Utah State University provided the logistical support for this study.

\title{
Resumen
}

\begin{abstract}
S. Rivera, J.L. Kershner y G.R. Keller. 2009. Tratamientos de la superficie de rodadura para reducir la erosión en caminos forestales en Honduras. Cien. Inv. Agr. 36(3):425-432. Los caminos forestales producen mas erosión y sedimentación que cualquier otra actividad agricola o forestal. En la parte central de Honduras, las perdidas de suelo producidas en la superficie de caminos forestales fueron evaluadas por dos años consecutivos. En la superficie del camino, se establecieron $400 \mathrm{~m}$ de camino en los cuales se colocaron ocho unidades experimentales de $50 \mathrm{~m}$ de longitud. Cuatro unidades fueron tratadas, mientras que cuatro no fueron tratadas y se dejaron como testigos. Los tratamientos aplicados fueron: conformado del prisma del camino, instalación de alcantarillas y limpieza y conformado de cunetas, compactación en capas de 20 $\mathrm{cm}$ con material selecto, bombeo de la superficie del camino con una pendiente transversal doble de $3 \%$, una pendiente longitudinal menor del $12 \%$ y una capa de $10 \mathrm{~cm}$ de grava triturada (a $1 / 4$ inch $=0.63 \mathrm{~cm}$ ). Los movimientos de suelo fueron medidos durante las estaciones de lluvia. Los resultados finales mostraron que las perdidas de suelos en los segmentos no tratados fueron de alrededor de $500 \mathrm{~m}^{3} \cdot \mathrm{km}^{-1}$ por año, mientras que en los segmentos tratados resultó cerca de $225 \mathrm{~m}^{3} \cdot \mathrm{km}^{-1}$ por año, mostrando que la erosión de la superficie del camino puede ser reducida hasta en un $50 \%$ con tratamientos de la superficie.
\end{abstract}

Palabras clave: Bosque, caminos forestales, erosión, Honduras, manejo, superficie de rodadura, bosque tropical, suelo.

\section{References}

Blaney, D.G., and G.E. Warrington. 1983. Estimating soil erosion using an erosion bridge, $55 \mathrm{pp}$., Watershed Systems Development Group. WSDG Report WSDG-TP-0008, USDA For. Ser., Colorado, USA.

Brooks, K.N., P.F. Ffolliot, H.M. Gregersen, and J.L. Thames. 1991. Hydrology and Management of Watersheds, 392 pp, Iowa State University Press,
Ames, Iowa.

Burroughs, E.R., and J.G. King. 1989. Reduction of soil erosion on forest roads. USDA Forest Service Intermountain Research Station, 78 pp., U.S. For. Serv. Gen. Tech. Rep. INT-274.

FAO. 1989. Watershed Management Field Manual. Road Design and Construction in Sensitive Watersheds. Food and Agricultural Organization of the United Nations, FAO, Press. Rome, Italy. 405 pp.

Gollin, J.D. 1994. Trees down, lights out in Hon- 
duras, Habitat, The Christian Science Monitor. Nov. 15, 1994, 13-14.

Gray, D.H., and R.B. Sotir. 1996. Biotechnical and Soil Bioengineering Slope Stabilization, a Practical Guide for Erosion Control. John Wiley and Sons, Inc. NJ, USA.378 pp.

Laboranti, C. 1992. Diagnóstico hidrológico de las cuencas hidrográficas de Honduras, (Hydrological Diagnostic of Watershed in Honduras). Programa Nacional de Manejo de Cuencas, OEAGobierno de Honduras. Tegucigalpa, Honduras. $126 \mathrm{pp}$.

Lal, R. 1975. Analysis of factors affecting rainfall erosivity and soil erodability in, soil conservation and management in the humid tropics. Pages 125-138. In: D. J. Greenland and R. Lal (eds.). John Wiley and Sons. NJ, USA.

Megahan, W.F. 1980. Nonpoint source pollution from forestry activities in the western United States: results of recent research and research needs. Intermountain Forest and Range Experimental Station. USDA Forest Service, Boise Idaho., paper presented at the Conference on U.S. Forestry and Water Quality: What Course in the 80's? Water Pollution Control Federation, Richmond, Virginia, 19-20, June.

Megahan, W.F. 1980. Road effects and impacts-Wa- tershed, paper presented at Forest Transportation Symposium; Department of Agriculture, Forest Service, Rocky Mountain region, Engineering Staff unit, Casper, WY. Lakewood, CO: 11-13 December.

Rivera, S., J. L. Kershner, and J. P. Dobrowolski. 2008. A pilot project measuring surface erosion from different timber yarding methods in Honduras. Manuscript submitted to Arvore - Brazilian Journal of Forest Science in Dec. 2008.

Seyedbagheri, K.A.1996. Idaho forestry Best Management Practices: compilation of research on their effectiveness U.S. For. Serv. Gen. Tech. Rep. INT-GTR 339, 90 pp., US For. Ser. Intermountain Research Station, Boise, ID.

Sidle, R.C. 1980. Impacts of forest practices on surface erosion, 50 pp., Department of Forest Engineering, Oregon State University, Corvallis, OR.

US Forest Service. 1993. Soil and Water Conservation Handbook, FSH 2509.22, Juneau, Alaska. 105 pp.

World Bank. 2003. World Development Report 2000/2001-Attacking Poverty. Washington D.C. 355 pp.

Zar, J.H. 1999. Biostatistical analysis. Fourth ed. Prentice Hall. NJ, USA, 660 pp. 